\title{
Strategi dan Pertimbangan Etis dalam Penulisan Proposal Penelitian Ilmu Perpustakaan dan Informasi
}

\author{
Oleh Mufid \\ Pustakawan UIN Maulana Malik Ibrahim Malang \\ mufid@uin-malang.ac.id
}

\begin{abstract}
In the preparation of an effective research proposal in library and information science, a researcher needs to have a proposal writing strategy, and to understand of the ethical issues of research either through qualitative, quantitative or mixed methods. Therefore, this paper aims to provide a guidance for a researcher about writing strategies that includes nine key elements of the arguments, the research proposal outlines, the effectively research proposal writing stages, and the ethical issues during the research. The ability of a researcher to choose a strategy, and to understand the ethical issues of research is very important. Its will determine the quality of research outputs.
\end{abstract}

Key Words: research proposals, research outlines, research ethics

\begin{abstract}
Abstrak
Dalam penyusunan proposal penelitian yang efektif bidang ilmu perpustakaan dan informasi, seorang peneliti perlu memiliki strategi penulisan proposal, dan memahami masalah-masalah etika penelitian baik melalui metode kualitatif, kuantitatif maupun metode campuran. Oleh karena itu, makalah ini bertujuan memberikan panduan bagi seorang peneliti mengenai strategi-strategi penulisan yang mencakup sembilan elemen kunci argumen, struktur (outline) proposal, tahapan penulisan proposal secara efektif, dan masalah-masalah etika selama penelitian berlangsung. Kemampuan peneliti memilih suatu strategi penulisan dan memahami masalah-masalah etika penelitian adalah sangat penting. Kemampuan ini akan menentukan kualitas hasil penelitian.
\end{abstract}

Kata kunci: Prposal penelitian, struktur pproposal, masalah etika penelitian

\section{Pendahuluan}

Dalam menyusun proposal penelitian yang baik dalam ilmu perpustakaan dan informasi, peneliti perlu memiliki suatu strategi menulis dan memahami masalah etika penelitian. Kemampuan peneliti dalam memilih strategi menulis dan memahami masalah etika penelitian akan menentukan kualitas hasil penelitian. Namun jika peneliti tidak memiliki 
kemampuan tersebut, hasil penelitiannya bisa diragukan secara ilmiah dan akan memunculkan masalah baru. Hal ini bertentangan dengan tujuan penelitian yang digunakan untuk memahami, memecahkan dan mengantisipasi masalah (Sugiyono, 2011) dan untuk pengembangan ilmu pengetahuan dan teknologi bagi kemanusiaan (Lembaga Ilmu Pengetahuan Indonesia, 2013).

Strategi apa yang perlu diketahui peneliti tentang penulisan proposal penelitian? Creswell (2013) menjelaskan strategi yang perlu dipahami dalam mendesain proposal yang baik meliputi strategi mengemukaan sembilan argumen pokok dan menyusun struktur (outline) proposal penelitian. Struktur penjelasan argumen berbeda dalam setiap pendekatan penelitian (kualitatif, kuantitatif dan metode campuran). Kemampuan memahami argumen pokok tersebut, peneliti akan diarahkan pada pemilihan pendekatan penelitian yang sesuai dengan masalah yang dikaji. Ketepatan dalam memilih pendekatan dan argumen-argumen yang disajikan peneliti dalam proposal secara tepat, akan membentuk fondasi yang baik bagi penyusunan proposal secara keseluruhan. Sementara hasil penelitian menunjukkan penerapan metode campuran dalam bidang ilmu perpustakaan dan informasi belum digunakan secara umum/lazim dan belum dibahas secara mendalam (Fidel, 2008).

Masalah-masalah apa yang perlu diketahui peneliti tentang etika penelitian? Peneliti juga perlu mengantispasi masalah-masalah etis yang bisa terjadi selama proses penelitian berlangsung. Creswell (2013) menjelaskan secara detail terkait dengan tempat berlangsungnya masalah etis selama proses penelitian yaitu sebelum pelaksanaan penelitian, memulai penelitian, mengumpulkan data, menganalisis data, melaporkan, berbagi dan menyimpan data.

Masalah etis ini menjadi unsur penting dalam membangun argumentasi dan menentukan topik. Peneliti perlu melindungi partisipan, membangun kepercayaan partisipan, berusaha jujur dalam penelitian, mencegah kelalaian dan kecerobohan yang dapat mencemarkan nama baik organisasi atau institusinya, dan berupaya untuk mengatasi masalah yang dihadapi dengan arif dan bijaksana (Israel \& Hay dalam Creswell 2013). Pentingnya penegakan kode etik peneliti juga telah dinyatakan secara tegas dalam peraturan Kepala Lembaga Ilmu Pengetahuan Indonesia (2013) adalah menjaga marwah profesi, kualitas penelitian dan kredibilitas lembaga penelitian. Untuk itu kode etik sangat bermanfaat untuk menjadi ramburambu etika dalam penelitian. Hal ini penting diungkapkan dalam strategi penulisan proposal penelitian karena terkadang para peneliti belum memahami dan mengabaikan masalah etika penelitian. 


\section{Strategi Menulis Proposal}

\section{Mengemukaan Argumentasi Pokok dalam Proposal Penelitian}

Setiap proposal penelitian perlu diulas dengan argumentasi yang kuat dan menarik perhatian pembaca. Argumen-argumen yang menjelaskan topik-topik proposal diulas secara kohesif dengan bahasa yang mudah untuk dipahami pembaca. Creswell (2013) menjelaskan bahwa ada sembilan argumentasi untuk menjelaskan topik penelitian baik kualitatif, kuantitatif maupun metode campuran. Sembilan argumen penting yang perlu dikemukaan dalam proposal penelitian adalah:

1. Apa yang diperlukan pembaca untuk lebih memahami topik Anda?

2. Apa yang perlu diketahui pembaca tentang topik Anda?

3. Apa yang Anda usulkan untuk diteliti?

4. Siapa orang yang akan Anda teliti?

5. Metode apa yang akan Anda gunakan untuk mengumpulkan data?

6. Bagaimana Anda akan menganalisis data?

7. Bagaimana Anda akan memvalidasi temuan Anda?

8. Isu etika apa yang akan Anda pelajari saat ini?

9. Apa hasil awal yang menunjukkan tentang kepraktisan dan nilai dari studi yang diajukan?

Argumen tersebut akan mengarahkan peneliti pada pendekatan penelitian apa yang sesuai dengan topik yang dikaji apakah pendekatan penelitian kuantitatif, kualitatif atau metode campuran. Sembilan argumen tersebut menunjukkan bagian-bagian pokok dari struktur (outline) penelitian yang perlu dikemukakan. Argumen di atas menunjukkan pentingnya topik bagi pembaca $(1,2)$, tujuan penelitian (3), pengumpulan data melalui partisipan (4), metode pengumpulan data (5), analisis data (6), validasi data (7), etika penelitian (8), dan implikasi /manfaat penelitian (9). Etika penelitian merupakan komponen yang menarik dan penting untuk diungkapkan namun terkadang tidak diungkap dalam proposal penelitian. Masalah etika ini perlu diantisipasi dan dijelaskan diseluruh proses penelitian. Peneliti harus mengetahui batas-batas etis untuk menghindari terjadinya persoalan baru dalam penelitian karena tujuan penelitian itu 
menberikan kontribusi dalam penyelesaian masalah bukan sebaliknya menambah masalah baru.

\section{Membuat Struktur Proposal (Outlines) Penelitian}

Strategi untuk menyusun proposal selain dengan mempertimbangan sembilan argumen di atas, juga diperlukan untuk membuat struktur (outline) yang menggambarkan topik-topik umum yang akan dijelaskan dalam proposal. Penelitian kualitatif, kuantitatif dan metode campuran memiliki perbedaan strukturnya. Sebagai gambaran di bawah ini akan dijelaskan tiga contoh model struktur proposal kualitatif, kuantitatif dan metode campuran menurut Creswell (2013). Model yang ditawarkan tersebut memberikan gambaran perbedaan dari pendekatan penelitian yang diterapkan peneliti.

\section{Struktur Proposal Kualitatif}

Struktur proposal kualitatif tidak ada format umum yang diberlakukan sebagai model pasti, namun struktur proposal kualitatif yang diperlukan untuk bisa dijadikan pijakan meliputi:

\section{Pendahuluan}

- Latar belakang masalah: mencakup literature yang berhubungan dengan masalah tersebut dan relevansi (penting) nya penelitian bagi pembaca.

- Tujuan penelitian

- Rumusan masalah (pertanyaan penelitian)

Prosedur

- Asumsi filosofis penelitian kualitatif

- Rancangan penelitian (misalnya, etnografi, studi kasus)

- Peran peneliti

- Prosedur pengumpulan data

- Prosedur analisis data

- Strategi menvalidasi temuan

- Struktur naratif penelitian yang diajukan

- Masalah etis yang mungkin muncul

Temuan-temuan awal/pendahuluan (jika ada) 
Dampak dan signifikansi penelitian yang diharapkan

Daftar pustaka

Lampiran (pertanyaan wawancara, bentuk-bentuk observasi, jadwal, anggaran yang diajukan, ringkasan isi tiap-tiap bab dalam penelitian akhir)

Model di atas menunjukkan bahwa ada lima komponen utama yang diungkapkan oleh peneliti yaitu pendahuluan, prosedur, masalah etis, temuan pendahuluan, dan dampak penelitian yang diharapkan. Untuk tinjauan pustaka bisa dimasukkan hanya bersifat pilihan. Sementara lampiran memberikan informasi sangat berguna bagi para pemberi dana.

\section{Format Proposal Kuantitatif}

Struktur proposal kuantitatif memiliki format umum. Format ini biasanya dapat dijumpai dalam artikel jurnal kuantitatif. Secara garis besar, format proposal kuantitatif mencakup pendahuluan, tinjauan pustaka, metode, hasil dan diskusi. Uraian format proposal kuantitatif sebagai berikut:

\section{Pendahuluan}

- Latar belakang masalah (mencakup pembahasan masalah yang diangkat dan pentingnya penelitian).

- Tujuan penelitian

- Rumusan masalah atau hipotesis

- Perspektif teoritis

Tinjauan pustaka (teori dimasukkan di sini bukan di bagian pendahuluan)

Metode penelitian

- Jenis rancangan penelitian (mis. Eksperimen, survei)

- Populasi, sampel, dan partisipan

- Instrument, variabel, dan materi pengumpulan data

- Prosedur analisis data

- Masalah etis yang mungkin muncul

Penelitian pendahuluan atau pengujian awal

Daftar pustaka 
Lampiran (Instrumen, jadwal, anggaran yang diajukan)

\section{Format Proposal Metode Campuran}

Format struktur proposal metode campuran merupakan gabungan dari format kuantitatif dan kualitatif. Formatnya dapat dijelaskan sebagai berikut:

\section{Pendahuluan}

- Latarbelakang masalah (penelitian sebelumnya yang juga membahas masalah tersebut, kekurangan dalam penelitian sebelumnya, dan manfaat penelitian bagi pembaca)

- Tujuan atau sasaran penelitian dan alasan digunakannya penelitian metode campuran.

- Rumusan masalah dan hipotesis (rumusan masalah atau hipotesis kuantitatif, rumusan masalah kualitatif, rumusan masalah metode campuran)

- Landasan filosofis tentang penelitian metode campuran

- Tinjauan pustaka (tinjauan optional kuantitatif, tinjauan kualitatif, dan tinjauan metode campuran)

\section{Metode}

- Definisi penelitian metode campuran

- Jenis rancangan yang digunakan dan definisinya

- Tantangan menggunakan rancangan ini dan bagaimana menghadapi tantangan tersebut.

- Contoh penerapan rancangan tersebut. Referensi dan penyertaan diagram prosedur.

- Pengumpulan data kuantitatif.

- Analisis data kualitatif

- Pengumulan data kualitatif

- Analisis data kualitatif

- Prosedur analisis data metode campuran

- Pendekatan dalam menvalidasi data kuantitatif dan kualitatif 
Sumber dan keterampilan peniliti dalam melaksanakan penelitian metode campuran

Masalah etis yang mungkin muncul Referensi

Lampiran: instrument penelitian, protocol penelitian, jadwal, anggaran, dan ringkasan isi utama dari setiap bab.

Format di atas menunjukkan bahwa format proposal metode campuran lebih panjang dari format kualitatif dan kuantitatif. Perbedaan ini karena format strukturnya mengkombinasikan format kuantitatif dan kualitatif. Menurut Sugiyono (2011) hasil penelitian yang menggunakan metode campuran/kombinasi akan menghasilkan data yang lebih komprehensif, valid, reliabel dan obyektif.

\section{Memahami Tahapan Menulis Proposal Penelitian}

Selanjutnya untuk menulis proposal secara efektif, diperlukan panduan yang runtut dari tahap awal hingga akhir proses penulisan. Ada banyak panduan praktis langkah-langkah menulis proposal yang dibuat oleh perguruan tinggi atau pusat penelitian. Misalnya, The University of Wisconsin-Madison's Writing Center (2017) membuat panduan praktis, sederhana dan fleksibel yang terdiri dari delapan langkah/tahapan dalam menulis proposal. Berikut tahapan menulis proposal penelitian dari hasil adopsi panduan Writer Center:

Tahapan

1. Menemukan, mempersempit, dan memfokuskan topik yang dapat diteliti
Uraian Kegiatan

- Temukan topik yang benar-benar menarik minat Anda

- Tentukan topik Anda

- Diskusikan dengan kolega pustakawan atau asosiasi

- Buat topik tersebut sebagai pertanyaan yang harus dijawab atau masalah yang harus dipecahkan
2. Mencari, Memilih, dan Membaca Sumber

- Katalog perpustakaan, indeks berkala, bibliografi, saran dari kolega pustakawan

- Sumber primer vs sekunder

- Jurnal, buku, dokumen lainnya

3. Mengelompokkan, mengurutkan dan
- Gunakan aplikasi pengelolaan referensi (Management Reference Software) misalnya, 
mendokumentasikan informasi

mendokumentasikan informasi

- Membuat ringkasan isi referensi
- Apa topiknya?

- Mengapa itu penting?

- Materi latar belakang apa yang relevan?

- Apa tujuan penelitian Anda?
- Gunakan referensi latar belakang yang relevan

- Definiskan istilah atau konsep bila diperlukan

- Jelaskan fokus tujuan proposal penelitian anda
- Gunakan garis besar sebagai panduan fleksibel

- Bangun argumen yang ingin Anda buat (yaitu, jangan biarkan sumber Anda mengatur proposal Anda)

- Integrasikan sumber Anda ke dalam diskusi Anda

- Meringkas, menganalisa, menjelaskan, dan mengevaluasi karya yang diterbitkan bukan sekadar melaporkannya

- Baca proposal anda dari urutan umum ke khusus, dan sebaliknya (ladder of abstraction)
- Bahasa kesimpulan mudah dipahami pembaca Anda.

- Kesimpulan merupakan ringkasan jawaban atas rumusan masalah yang terdapat pada pendahuluan.

- Saran untuk penelitian lebih lanjut / rekomendasi
- Periksa keseluruhan susunan proposal: uraian pendahuluan logis, koherensi dan kedalaman diskusi isi proposal, efektivitas kesimpulan.

- Kepentingan tingkat paragraf: kalimat topik, urutan gagasan dalam paragraf, penggunaan rincian untuk mendukung generalisasi, kalimat ringkasan jika perlu, penggunaan transisi di dalam dan di antara paragraf.

- Kepentingan tingkat kalimat: struktur kalimat, pilihan kata, tanda baca, ejaan.

- Referencing styles: penggunaan satu sistem secara konsisten 
Pada tahap pertama adalah mengidentifikasi topik penelitian yang layak diteliti atau tidak. Ada dua hal yang penting dipahami oleh peneliti dalam menentukan topik yaitu apakah topik itu dapat diteliti dan perlu (urgensi) nya untuk diteliti (Creswell, 2013). Untuk menjawab topik itu dapat diteliti, peneliti sudah memiliki target partisipan yang mau membantu penelitiannya. Untuk menjawab penelitian perlu (urgensi) nya topik itu diteliti, maka peneliti harus mampu memahami apakah topik tersebut hanya menambah pengetahuan, menduplikasi penelitian sebelumnya, atau upaya menyuarakan kelompok masyarakat terpinggirkan. Dan juga harus dipertimbangkan apakah topik itu diperlukan oleh lembaga peneliti. Tahap kedua dan ketiga merupakan tahap untuk mencari sumber-sumber referensi yang mendukung topik yang diteliti. Semua referensi-referensi yang diperoleh, peneliti perlu membuat peta referensi untuk menunjukkan penelitian yang dilakukan sebelumnya. Pada tahapan ini peneliti dapat menentukan pendekatan penelitian yang cocok untuk diterapkan. Sementara tahap keempat sampai tahap akhir merupakan tahap menulis proposal. Setiap rancangan penelitian yang digunakan sesuai dengan pendekatan penelitian yang ditetapkan oleh peneliti.

\section{Menulis Gagasan Secara Efektif}

Bagian terpenting dari keberhasilan menulis proposal penelitian adalah kemauan untuk menyelesaikan proposal. Kegagalan menulis proposal bisa dikarenakan faktor tidak konsisten / disiplin menulis. Akibatnya, kejenuhan akan dialami peneliti karena harus mengulang lagi baik dari sisi pembacaan literatur maupun terganggu oleh aktivitas-aktivitas yang lain. Untuk itu maka penulis perlu memiliki strategi dalam menuliskan gagasan. Menurut Creswell (2013) dalam proses menulis gagasan, ada empat strategi yang perlu dipertimbangkan, antara lain:

\section{Menulis seperti berfikir}

a. Pada awal proses penelitian, lebih mengutamakan menuliskan gagasan-gagasan daripada membicarakannya.

b. Lebih baik mengerjakan beberapa draf proposal daripada memoles draf pertama

c. Jangan mengedit proposal pada tahap-tahap pertama

2. Kebiasaan/kedisiplinan menulis. Untuk membangun kedisiplinan menulis ada beberapa strategi yang bisa dilakukan, antara lain; 
a. Menuliskan aktifitas keseharian

b. Memetakan aktivitas

c. Memberikan waktu setengah jam untuk menulis

d. Menulis saat suasana menyenangkan

e. Jangan menulis saat kekenyangan

f. Menaati jadwal menulis

3. Keterbacaan / mutu naskah

a. Gunakan istilah yang konsisten dalam seluruh proposal

b. Uaraian gagasan proposal sesuai dengan pemahaman pembaca

4. Kalimat aktif, kata kerja aktif, dan mengurangi kata-kata yang belebihan

\section{Masalah-masalah Etis yang Perlu Diantisipasi}

Masalah etis merupakan masalah penting yang perlu dipertimbangkan oleh peneliti dalam menyusun proposal penelitian. Hampir semua lembaga penelitian telah menetapkan kode etik penelitian sebagai standar etika penelitian. Misalnya, peraturan kode etik yang dibuat oleh Kepala Lembaga Ilmu Pengetahuan Indonesia (2013) yang menyatakaan bahwa "Kode Etika Peneliti adalah acuan moral bagi peneliti dalam melaksanakan penelitian untuk pengembangan ilmu pengetahuan dan teknologi bagi kemanusiaan. Ini menjadi suatu bentuk pengabdian dan tanggung jawab sosial dan ketaqwaan kepada Tuhan Yang Maha Esa". Selanjutnya dalam peraturan ini seorang peneliti memiliki 4 (empat) tanggung jawab dalam penelitian, yaitu:

- Terhadap proses penelitian yang memenuhi baku ilmiah.

- Terhadap hasil penelitiannya yang memajukan ilmu pengetahuan sebagai landasan kesejahteraan manusia.

- Kepada masyarakat ilmiah yang memberi pengakuan di bidang keilmuan peneliti tersebut itu sebagai bagian dari peningkatan peradaban manusia.

- Bagi kehormatan lembaga yang mendukung pelaksanaan penelitiannya.

Kode etika peneliti ini meliputi kode etik dalam penelitian, berperilaku dan dalam kepengarangan yang diuraikan dalam Sembilan kode etik meliputi: 


\begin{tabular}{ll}
\hline dalam penelitian & $\begin{array}{l}\text { menghasilkan inovasi bagi peningkatan peradaban dan kesejahteraan } \\
\text { manusia. }\end{array}$ \\
& Kode kedua, Peneliti melakukan kegiatannya dalam cakupan dan batasan \\
& yang diperkenankan oleh hukum yang berlaku, bertindak dengan \\
& mendahulukan kepentingan dan keselamatan semua pihak yang terkait \\
& dengan penelitiannya, berlandaskan tujuan mulia berupa penegakan hak- \\
& hak asasi manusia dengan kebebasan-kebebasan mendasarnya.
\end{tabular}

Kode ketiga, Peneliti mengelola sumber daya keilmuan dengan penuh rasa tanggung jawab, terutama dalam pemanfaatannya, dan mensyukuri nikmat anugerah tersedianya sumber daya keilmuan baginya.

Kode etika Kode keempat, Peneliti mengelola jalannya penelitian secara jujur, dalam bernurani, dan berkeadilan terhadap lingkungan penelitiannya.

berperilaku

Kode kelima, Peneliti menghormati objek penelitian manusia, sumber daya alam hayati dan non-hayati secara bermoral, berbuat sesuai dengan perkenan kodrat dan karakter objek penelitiannya, tanpa diskriminasi dan tanpa menimbulkan rasa merendahkan martabat sesama ciptaan Tuhan.

Kode keenam, Peneliti membuka diri terhadap tanggapan, kritik, dan saran dari sesama Peneliti terhadap proses dan hasil penelitian, yang diberinya kesempatan dan perlakuan timbal balik yang setara dan setimpal, saling menghormati melalui diskusi dan pertukaran pengalaman dan informasi ilmiah yang objektif.

Kode etika Kode ketujuh, Peneliti mengelola, melaksanakan, dan melaporkan hasil dalam penelitian ilmiahnya secara bertanggung jawab, cermat, dan seksama.

kepengarangan

Kode kedelapan, Peneliti menyebarkan informasi tertulis dari hasil penelitiannya, informasi pendalaman pemahaman ilmiah dan/atau pengetahuan baru yang terungkap dan diperolehnya, disampaikan ke dunia ilmu pengetahuan pertama kali dan sekali, tanpa mengenal publikasi duplikasi atau berganda atau diulang-ulang.

Kode kesembilan, Peneliti memberikan pengakuan melalui: penyertaan sebagai penulis pendamping; pengutipan pernyataan atau pemikiran orang lain; dan/atau dalam bentuk ucapan terima kasih yang tulus kepada Peneliti yang memberikan sumbangan berarti dalam penelitiannya, yang secara nyata mengikuti tahapan rancangan penelitian dimaksud, dan mengikuti dari dekat jalannya penelitian itu.

Batasan-batasan atau rambu-rambu etika penelitian di atas menunjukkan bahwa seorang peneliti harus memahami kode etik agar penelitian yang dilakukan tidak menimbulkan masalah di kemudian hari. 
Semangat peratuan tentang kode etik penelitian di atas adalah untuk dijadikan acuan atau rambu-rambu bagi peneliti dalam melaksanakan penelitian untuk pengembangan ilmu pengetahuan dan teknologi bagi kemanusiaan. Oleh karena itu, bagi peneliti yang melanggar kode etik akan diberikan sanksi etis. Sanksi ini ditentukan oleh Majelis Pertimbangan Etika Peneliti (MPEP) yang bertugas untuk memberikan sanksi teguran tertulis sampai dengan pengumuman terbuka kepada masyarakat profesi serta rekomendasi pemecatan dari jabatan fungsional Peneliti dan/atau pembatalan pengukuhan profesor riset (Lembaga Ilmu Pengetahuan Indonesia, 2013).

Selanjutnya, bagaimana langkah-langkah praktis penerapan kode etik itu selama proses penelitian berlangsung? Menurut Creswell, (2013) masalah-masalah etis yang perlu dipertimbangan dalam menyusun proposal selama berlangsungnya proses penelitian meliputi:

- Sebelum meneliti : Kode etik, persetujuan universitas, mendapatkan ijin penelitian, pemilihan lokasi tidak dipengaruhi oleh kepentingan pribadi, menegoisasi hak kepenulisan untuk publikasi

- Memulai menulis: identifikasi masalah, tujuan penelitian, tidak ada paksaan terhadap responden/partisipan, mengahargai norma penduduk local

- Mengumpulkan data: menhormati lokasi penelitian, memperlakukan sama semua partisipan

- Menganalisis data: menghindari keperpihakan pada partisipan, menghindari hanya mengungkapkan hal positif, menghormati privasi partisipan,

- Laporan, berbagi dan menyimpan data: menghindari pemalsuan data, plagiat, informasi yang membahayakan partisipan, bahasa yang jelas, menyimpan data mentah dan materi materi lain, tidak menduplikasi atau melakukan publikasi sedikit demi sedikit, memberikan bukti lengkap

\section{Perkembangan Penerapan Metode Penelitian dalam Ilmu Perpustakaan dan Informasi}

Saat ini muncul tiga gerakan metodologis dalam proyek penelitian ilmu sosial dan perilaku: kuantitatif (analisis angka), kualitatif (analisis data naratif), dan metode campuran (pengabungan dua jenis data) (Tashakkori \& Teddlie, 2003). Metode campuran digunakan sebagai pendekatan ilmu sosial dan perilaku selama lebih dari tiga dekade (Fidel, 2008). Namun, penerapan 
metode campuran dalam bidang ilmu perpustakaan dan informasi belum digunakan secara umum/lazim dan belum dibahas secara mendalam. Hasil penelitian yang dilakukan oleh Fidel, (2008) menemukan hanya 22 artikel (5\%) dari 465 artikel yang diteliti. Artikel tsb berasal dari 4 jurnal terkemuka (Information Processing and Management, Journal of Documentation, Journal of the American Society for Information Science and Technology, Library and Information Science Research). Fakta ini, diperkuat oleh pendapat Busha dalam Connaway \& Powell (2010), "bahwa penelitian kepustakawanan masih tergolong muda. Konsep yang jelas tentang tujuan, sasaran, dan metodologi penelitian ilmu perpustakaan baru sekarang mulai diformulasikan dengan kokoh.

Atas dasar temuan ini, sesungguhnya pendekatan metode campuran bisa diterapkan dalam ilmu perpustakaan dan informasi. Ke depan ilmu perpustakaan akan "semakin membutuhkan untuk menggunakan metodologi disiplin ilmu lainnya - khususnya, ilmu sosiologi, psikologi, ekonomi, linguistik, sejarah - dan menerapkan metodologi yang lebih umum untuk mempelajari masalah-masalah yang dihadapi kepustakawanan saat ini" (Vickery dalam Connaway \& Powell, 2010). Hal ini menjadi peluang bagi peneliti untuk mempelajari metode campuran secara mendalam sebagai alternatif dalam mengkaji ilmu perpustakaan dan informasi.

\section{Kesimpulan}

Sebelum meneliti, seorang peneliti pemula perlu memahami strategi dan pertimbangan etis dalam penulisan proposal penelitian. Pemahaman peneliti tentang sembilan argumentasi kunci yang perlu dimasukkan dalam proposal penelitian sangat penting untuk menentukan pendekatan penelitiannya. Tahapan-tahapan menulis proposal yang dijelaskan di atas memberikan panduan praktis bagi peneliti pemula untuk membuat proposal yang baik dan efektif. Penjelasan masalah etis di atas, juga komponen sangat penting dalam penyusunan proposal penelitian untuk mengantisipasi masalah-masalah yang muncul pada semua tahapan dalam proses penelitian.

Dalam perkembangan kajian ilmu perpustakaan dan informasi, metode penelitian yang digunakan masih sedikit yang menerapkan metode campuran (mixed methods). Hal ini menggambarkan bahwa para peneliti bidang ilmu perpustakaan dan informasi belum sepenuhnya mengenal metode campuran sebagai alternatif dalam mengungkap permasalahan penelitian. Ke depan, sebaiknya para peneliti dalam kajian ilmu perpustakaan dan informasi sudah mengarahkan perhatiannya ke arah pendekatan metode campuran untuk mendapatkan hasil yang lebih komprehensif. 


\section{Daftar Rujukan}

Connaway, L. S., \& Powell, R. R. (2010). Basic research methods for librarians. Santa Barbaa, California: Libraries Unlimited.

Creswell, J. W. (2013). Research Design: Qualitative, Quantitative, and Mixed Methods Approaches. Research design Qualitative quantitative and mixed methods approaches. Thousand Oaks, California: SAGE Publications, Inc. https://doi.org/10.1007/s13398-014-0173-7.2

Fidel, R. (2008). Are we there yet?: Mixed methods research in library and information science. Library and Information Science Research, 30(4), 265-272. https://doi.org/10.1016/j.lisr.2008.04.001

Lembaga Ilmu Pengetahuan Indonesia. Peraturan Kepala lembaga Ilmu Pengetahuan Indonesian Nomor: 06/E/2013 Tentang Kode Etika Peneliti, Pub. L. No. 06/E/2013, 21 (2013). Retrieved from http://pusbindiklat.lipi.go.id/wp-content/uploads/Perka-LIPI-tentangKode-Etika-Peneliti.pdf

Sugiyono, S. (2011). Metode penelitian kombinasi (mixed methods). Bandung: Alfabeta.

Tashakkori, A., \& Teddlie, C. (2003). Handbook of mixed methods in social \&amp; behavioral research. Thousand Oaks Calif.: SAGE

Publications. Retrieved from http://www.worldcat.org/title/handbookof-mixed-methods-in-social-behavioral-

research/oclc/318407040\&referer=brief_results

The University of Wisconsin-Madison's Writing Center. (2017). Academic and Professional Writing: Writing a Research Paper. Retrieved October 29, 2017, from https://writing.wisc.edu/Handbook/PlanResearchPaper.html 